\title{
As eleições brasileiras para o Parlamento do MERCOSUL em 2014
}

\author{
João Paulo Falavinha Marcon ${ }^{1}$
}

\section{RESUMO}

O Parlamento do MERCOSUL, do qual o Brasil faz parte, elegerá novos representantes no ano de 2014. Assim, o presente texto visa a expor, brevemente, como o país latinoamericano está tratando o tema.

Palavras-chave: Brasil; MERCOSUL; Parlasul; Eleições; Representação.

O Parlamento do MERCOSUL, também denominado de Parlasul, constitui-se no órgão democrático de representação civil da diversidade ideológica e política dos povos de seus países-membros, quais sejam: Brasil, Argentina, Paraguai, Uruguai e Venezuela (cujo processo de adesão formal ao grupo encontra-se em andamento). Sua criação formal deu-se em 9 de dezembro de 2005, sendo que a primeira reunião do órgão só veio a ocorrer em 7 de maio de 2007. Está sito na cidade de Montevidéu e se compõe por 90 deputados (18 de cada país-membro).

O Brasil, assim como os demais integrantes, possui assento permanente na câmara legislativa, fazendo-se representar por deputados e senadores nacionais do país que se encontram em pleno exercício de seus mandatos. Significa dizer: os políticos brasileiros que atuam no Parlasul são os mesmos eleitos para trabalharem no Congresso Nacional Brasileiro. Ainda não há eleições diretas para aquele órgão, à exceção do Paraguai, que já procedeu a esta modalidade de sufrágio.

Nos termos do art. 6o do Protocolo Constitutivo do Parlamento do Mercosul, assinado em dezembro de 2005 por todos os membros, todos os parlamentares devem ser eleitos por sufrágio universal, em eleições internas gerais a serem realizadas por

\footnotetext{
${ }^{1}$ Advogado, especialista em Direito Internacional e Negócios Internacionais, mestrando pelo Programa de Pós-Graduação Stricto Sensu em Ciência Política da UFPR, pesquisador do Núcleo de Estudos e Pesquisas em Relações Internacionais (NEPRI) e membro da Comissão de Direito Internacional da OABPR.

Conjuntura Global, Curitiba, Vol. 2, n.1, jan./mar., 2013, p. 13-15. 
cada um dos Estados-membros, sendo que o prazo dado para tanto é 31 de dezembro de 2014.

A CCJ - Comissão de Constituição e Justiça e Cidadania - já aprovou as normas relativas à eleição de parlamentares brasileiros para o Parlasul, em 2014, perfazendo o total de 74 representantes. Porém, as regras fixas referentes a este procedimento só serão definidas após o pleito.

Um dos pontos já acertados é que os candidatos ao Parlamento não poderão concorrer, simultaneamente, em outras eleições internas, por exemplo, para deputados federais/estaduais ou senadores. 0 processo de votação se dará nos mesmos moldes do que se tem feito atualmente, ou seja, por meio de urnas eletrônicas e a apuração será feita com o mesmo cálculo, hoje, usado para definição de deputados no Brasil (quociente eleitoral), o que, por seu turno, dirá o número de vagas a que cada partido fará juz.

As vagas serão preenchidas de acordo com a ordem estabelecida nas listas partidárias e as normas para escolha, o ordenamento e eventuais substituições de candidatos ficarão a cargo dos partidos, quando da elaboração de seus estatutos.

0 texto que se encontra em andamento para aprovação final e sançãofveto pela Presidenta Dilma, estabelece, ademais, que os dez primeiros lugares das listas deverão ser ocupados por representantes das cinco regiões do país (Norte, Nordeste, CentroOeste, Sudeste e Sul), sendo que, dentre os dez, quatro deverão ser, necessariamente, mulheres.

E, para a conclusão do procedimento, falta o projeto ser aprovado pela Comissão de Finanças e Tributação, bem assim pelo Plenário, para, finalmente, chegarem às mãos da Chefe do Executivo, a qual poderá sancioná-lo (aprová-lo) integralmente, sugerir alterações ou vetá-lo na sua totalidade.

\section{Referências Bibliográficas}

MERCOSUL. Página Brasileira do Mercosul. Disponível em: http://www.mercosul.gov.br/; Acesso em: 0202/2013. 
O BLOG DE FOZ. Parlamento do Mercosul prazo até 2014 para eleições. Disponível em: http://blogdefoz.blogspot.com.br/2011/07/parlamento-do-mercosul-prazo-ate2014.html; Acesso em: 02/02/2013.

PARLAMENTO DEL MERCOSUR. Disponível http://www.parlamentodelmercosur.org/innovaportal/v/87/1/secretaria/home.h tml?seccion=1; Acesso em: 02/02/2013.

RIBEIRÃO PRETO ONLINE. Eleição para Parlamento do Mercosul terá lista fechada em 2014. Disponível em: http://www.ribeiraopretoonline.com.br/noticiasbrasilia/eleicao-para-parlamento-do-mercosul-tera-lista-fechada-em--2014/45643; Acesso em: 02/02/2013. 